$10.21867 / \mathrm{KjK} / 2016.2 .7$.

\title{
JOGÁLLAMI ÉS FENNTARTHATÓ IS EGYBEN? - NÉHÁNY GONDOLAT A HULLADÉKMENNYISÉG MÉRÉSE KAPCSÁN
}

\author{
Fodor László ${ }^{1}$
}

A hulladékok súly (szabatosan: tömeg) szerinti átvételének igényét fogalmazta meg Fogarasi József egy hozzászólásban. ${ }^{2} \mathrm{Ez}$ a megoldás $^{3}$ paradigmaváltást feltételez egyfelől annak megítélésében, hogy az ingatlanhasználók alapvető jogai mennyiben korlátozhatók környezetvédelmi érdekböl (hol az egyediesítés határa?), másfelöl abban a tekintetben is, hogy milyen szempontok szerint kell a közszolgáltatások (nem csak a hulladékkezelés) díjszabását kialakítani. A tanulmány ezt a két kérdést veti fel, s igyekszik a válaszadás lehetséges irányait felvázolni.

\section{A kérdésfelvetés háttere}

2012 végéig a települési önkormányzatok szabályozási jogköre a szilárd hulladékkezelési közszolgáltatás terén a jelenlegihez képest teljesebb volt: a szolgáltatásnyújtás tartalmi kérdései mellett a szolgáltatásért fizetendő díj mértékének meghatározására is kiterjedt. Ezt a hatáskört legutóbb két lépcsőben korlátozták, s mára csak bizonyos kiegészítő díjakra vonatkozik a hulladékról szóló 2012. évi CLXXXV. törvény ${ }^{4}$ (a továbbiakban Ht.) 35. § (1) bekezdés e) pontja értelmében. A rendszerváltást követő, 2012 végéig terjedő időszak e hatáskör gyakorlását illetően legalább két szakaszra bontható, mivel a hulladékgazdálkodásról szóló 2000:XLIII. törvény megszületéséig nem voltak törvényben szabott korlátai. A törvényi szabályozást megelőzően, a helyi szabályozási gyakorlatban mutatkozó visszásságokra válaszul elsősorban az Alkotmánybíróság rögzített szempontokat. ${ }^{5} \mathrm{~A}$ taláros testület arra törekedett, hogy az alkotmányi értékrend egyes elemeinek érvényt szerezzen. A díjszabással kapcsolatos jogállami követelmények közt kiemelte például a diszkriminációmentességet. ${ }^{6}$ Magánjogias megközelítésben a díjszabás arányossága ${ }^{7}$ is szerepet kapott, s ennek mibenléte a hulladék mennyisége és a díj mértéke közötti viszonyban, utóbbinak az elöbbihez igazításában állapíttatott meg. A jogalkotó 2000-ben törvénybe iktatta a legfontosabb elveket. Ez a megoldás azonban törékeny látszategyensúlyt hívott életre, illetve tartott fenn, amely mára anakronisztikussá vált. A mennyiséget ugyanis ténylegesen nem mérte senki, ehelyett a hulladékgyüjtő edény ürtartalmát vették (ahogy veszik még ma is) figyelembe.

A megoldás látszatjellege egyfelől abban ölt testet, hogy csaknem teljesen zárt és ellenőrzött anyagáramként vette alapul a hulladékkeletkezést és -kezelést, miközben a valóság ettől eltért és eltér ma is: nem annyi hulladék keletkezik, mint amennyit a közszolgáltatónak átadunk. A díjfizetési kötelezettség - ha csekély környezeti tudatossággal párosul - mindig a rendszer

\footnotetext{
${ }^{1}$ Fodor László, tanszékvezető egyetemi tanár, DE ÁJK. A tanulmány a K 115530 ny. sz. kutatási projekt keretében, a Nemzeti Kutatási, Fejlesztési és Innovációs Hivatal támogatásával készült.

${ }^{2} \mathrm{http}: / / w w w . k o z j a v a k . h u / e n / v a n-e-j o-m e g o l d a s$

${ }^{3}$ Amely egyébként a jelenlegi kormányzati intézkedések elemei között is szerepel. http://kozjavak.hu/hu/kesikkozpontositott-szemetszallitas-bevezetese

${ }^{4} \mathrm{http}: / /$ njt.hu/cgi_bin/njt_doc.cgi?docid=156602.316385\#foot_107_place

${ }^{5} \mathrm{http} / / / \mathrm{www} . k o z j a v a k . h \mathrm{u} / \mathrm{sites} /$ default/files/szilagyi.emese_mennyit_e_r_a_kozszolgaltatas.pdf

${ }^{6}$ Azonos élethelyzetre legyen azonos a szabályozás, de eltérőre különböző; így a nyaralótulajdonos és a lakóingatlan tulajdonosa eltérő díjat legyen köteles fizetni.

${ }^{7}$ A szolgáltatás és ellenszolgáltatás egyenértéküsége.
} 
lyukai felé tereli a hulladékáram egy részét. ${ }^{8}$ Másrészt lyukaknak éppen a környezettudatosság fejlődése érdekében is lennie kell: például a kerti hulladékot lehessen a kertben komposztálni, ${ }^{9}$ a külön gyüjtött csomagolási hulladékot külön vegyék át, ${ }^{10}$ vagy (ahol elöbbire még nincs mód, ott) ingyenesen az erre kijelölt gyüjtőpontokon a megfelelö edényekbe lehessen helyezni. ${ }^{11}$ Mindez végeredményben oda vezet, hogy egyfelöl a hulladékkezelés költségeit bizonyos mértékig áthárítjuk a következő nemzedékekre, illetőleg az ingatlanhasználók helyett az adófizetőkre, másfelől viszont - a szelektálással, illetve az azt követő hasznosítással vagy a komposztálással - csökkenthetjük azokat.

Ezzel újabb, az Alaptörvény XX. cikk (1) bekezdésében rögzített környezethez való joggal összefüggő, alkotmányossági problémákhoz érkeztünk, amelyek közül az egyikre a legújabb idők ombudsmani gyakorlata találóan mutat rá. ${ }^{12}$ Eszerint gyakran hiányzik a kisebb edényzet rendelkezésre bocsátása, illetve az olyan feltételek meghatározása, amelyek a szelektív hulladékgyüjtést és a vegyes összetételü, háztartási hulladék mennyiségének a csökkentését ösztönöznék. A két felvetett probléma egymáshoz kapcsolódása nyilvánvaló: a szolgáltató által biztosítandó edények méretének előírása, illetőleg - az önkormányzati rendelet és a közszolgáltató gyakorlata alapján biztosított kínálatból - a gyüjtőedény méretének kiválasztása határozza meg a fizetendő díj mértékét.

Ideális esetben tehát a díj akkora, amekkora az átadott hulladék mennyiségének megfelel, ekkor teljesülnek az Alkotmánybíróság elvei. A környezethez való jog szempontjából azonban ez önmagában kevés. E jog szempontjából azt is el kellene érni, hogy a díjmérték megfeleljen a szennyezö fizet elvének (fedezzen minden felmerülő költséget), s hogy minden hulladékot - környezeti szempontból - megfelelően kezeljenek.

Ennek a jognak a gyüjtőedény méretére nézve is további szempontja van: ideális esetben az edény akkora, amekkora a hulladékot képes befogadni. Legalább akkorának kell lennie, hogy az átadásra kerülő hulladék a gyüjtés alatt se okozzon problémákat, s legfeljebb akkorának, mint a kezelendő hulladék mennyisége, hogy az így elérhető díjcsökkenés komposztálásra, szelekcióra ösztönözzön. Az ideális eset azonban egyediesítést igényel. De lehet-e annyiféle méretü edényt kínálni, amennyi a tényleges hulladékmennyiség szerinti differenciálást lehetővé teszi? - Mint az ombudsman rámutat, e téren is vannak hiányosságok. ${ }^{13}$ És lehet-e településtípusok illetve ingatlantípusok szerint differenciálni? ${ }^{14}$ Figyelünk-e a nem kívánatos jelenségekre? ${ }^{15}$ Biztosítunk-e kellő rugalmasságot az egyediesítés során? ${ }^{16}$ Ahelyett, hogy elkalandoznék a környezetvédelem szabályozásának a módszertana irányában, ${ }^{17}$ visszatérek a szükebb témához.

\footnotetext{
${ }^{8}$ Illegális lerakás, hulladékégetés kertben vagy akár fütőberendezésben, nem csak a komposztálgató hulladék „elásása,” a szomszéd edényének használata.

"Így csökken a kezelendő hulladék mennyisége.

10 Így inkább teljesülhetnek a szelektív gyüjtésre illetőleg a kommunális lerakók egyes frakcióira elöírt arányok.

${ }^{11}$ Megjegyzem, a Ht. 39. §-ában foglalt előírás, miszerint a gyüjtőpontok szolgáltatásait csak az veheti igénybe, aki megfizette a közszolgáltatási díjat, nem tünik végrehajthatónak.

${ }^{12}$ Ld. erről egy kommentemet: http://www.kozjavak.hu/en/jogallami-de-fenntarthato-0

13 Bár egyes, nagyobb településeken már akár hatféle is választható. http://srvcom.debrecen.hu/testulet_tartalom/Testuletianyagok/hatrend/2013/402013.HTML

${ }^{14}$ Hiszen nem mindegy, lehet-e otthon komposztálni, van-e gyüjtőpont az elkülönítetten gyüjtött hulladéknak, illetőleg melyek az adott települési közszolgáltatás helyi sajátosságai.

${ }_{15}^{15}$ Például megakadályozzák-e a hivatalok az illegális hulladékégetést?

${ }^{16}$ Ha esetenként több hulladék keletkezik, mint amennyi az edénybe belefér, elérhető-e extra szolgáltatás?

${ }^{17}$ Hogyan lehet javítani a hatósági munka hatékonyságát, ösztönözni az ingatlanhasználók környezettudatos magatartását, miért nem lehet az üzemekhez hasonlóan szabályozni a háztartások anyagáramát?
} 


\section{A tömeg szerinti átvétel/díjfizetés kérdéséhez}

A gyüjtőedény térfogatához igazodó díjszabás ötlete nem ördögtől való volt a maga idején, az tulajdonképpen ma is megfelel az európai szabályozási gyakorlatnak. Más kérdés, hogy a lakosság hogyan viszonyul magához a szolgáltatáshoz; azokban az országokban, ${ }^{18}$ ahol már több évtizedes gyakorlata van a szelektív gyüjtésnek, a közintézmények példamutató gyakorlatának, a szolgáltatókkal való partneri viszonynak, kialakult a hulladékhasznosítási iparág, minden bizonnyal kevesebb probléma merül fel. A tömeg szerinti mérést ugyanakkor indokolhatja például, hogy a hulladékkezelési ágazat egyéb szegmenseiben ${ }^{19}$ a tömeget veszik alapul a díjszabásnál, vagy hogy a tömeg pontosabban mérhető az átvételkor, mint a térfogat. $^{20}$

A jogi kérdés azonban valójában nem a térfogat vagy tömeg szerinti átvétel dilemmája, hanem a mért (valós) és a fiktív mennyiség szerinti díjfizetés különbsége. Az előbbiről az utóbbira való átállást az indokolhatja, hogy a valós mennyiség utáni fizetés "jogállamibb," s környezeti szempontból fenntarthatóbb. ${ }^{21}$ A gyüjtőedénnyel kapcsolatos kérdésfeltevések közül a jogállamisági követelményként értelmezettek nagyrészt okafogyottá válnak, ${ }^{22}$ ha megvalósul a mérés szerinti átvétel illetve díjfizetés. Környezetvédelmi oldalról persze ez sem lehet tökéletes, hiszen a hulladék összetétele rendkívül sokféle, s a kezelés - vagy már akár az ingatlanon való gyüjtés - szempontjából sokszor nem csak a tömeg, hanem a térfogat is meghatározó szempont. Gondoljunk csak a pillepalackokra. Azonban ahol és amennyiben megoldható az elkülönített gyüjtés, ${ }^{23}$ az átvétel/mérés is ennek megfelelően történik, és az ingatlanhasználók környezettudatosan törekednek a térfogat csökkentésére, ${ }^{24}$ ez a kétely könnyen eloszlatható.

De van itt egy "súlyosabb" probléma is. Fogarasi József felvetette, hogy a tömeg szerinti átvételnek infrastrukturális feltételei vannak, amelyek jelenleg még nem teljesülnek, $s$ beruházást igényelnek. ${ }^{25}$ Másrészt, mint arra a Települési Önkormányzatok Szövetségének elnöke rámutat, ${ }^{26} \mathrm{a}$ "súly alapján fizetés... nem hatékony, mivel a szemétszállító cégek költségeinek a 75 százaléka állandó kiadás, és csak a negyede függ az elszállított hulladék súlyától, illetve mennyiségétől."

\section{A kéttényezős díj}

A tényleges tömeg (súly) szerinti díjfizetés persze nem szükségszerüen egytényezős közszolgáltatási díjat jelent. Nemcsak a hálózatos közszolgáltatások esetén alkalmazzák már régtől fogva a kéttényezős díjak (alapdíj - szolgáltatási díj) rendszerét, annak alkalmazását például a 64/2008 (III. 28.) Korm. rendelet $^{27}$ a hulladékágazatban is lehetővé tette. Ezzel a fogyasztó egyfelől az igénybevett szolgáltatás mennyisége, másfelől a szolgáltató

\footnotetext{
${ }^{18}$ Például Németország.

${ }^{19}$ A hulladékkezelő létesítményekbe, pl. egy égetőmübe való hulladékszállítás esetén.

${ }^{20}$ Ez ráadásul már a gyüjtés, előkezelés során is változhat.

${ }^{21}$ Amennyiben jobban ösztönöz a hulladékmennyiség csökkentésére.

${ }^{22}$ Ugyanakkor újra felmerülhet az üdülőingatlanoknál fizetendő díj arányosságának kérdése, amire a Ht. egységesen 50\%-ot ír elö.

${ }^{23}$ Például társasházakban ez egyelőre nem megoldott.

${ }^{24}$ Ismerik a “tapossa laposra!” előnyeit.

${ }^{25}$ Megjegyzendő: az ágazat a 2012 végén kezdődött átalakítás során forráshiányos helyzetbe került, sok helyen maga az ellátás is nehézségekbe ütközik. Megjegyzendő ugyanakkor az is, hogy a tömeget egyes szolgáltatók eddig is figyelembe vették, ha nem is a díjszabás során, hanem amennyiben maximálták az egy-egy gyüjtőedényben elhelyezhető hulladék "súlyát." Ez azt feltételezi, hogy mérni is tudták a tömeget, ha nem is hitelesített módon. http://www.nhszszolnok.hu/userfiles/Lakossagi_szerzoes_szolnok_2011_jav.pdf

${ }^{26} \mathrm{http}: / / \mathrm{hvg} . \mathrm{hu} / \mathrm{gazdasag} / 20160321$ nemzeti_kukaholding_szemetszallitas_hulladekkezeles_kuka

${ }^{27} \mathrm{http}: / /$ njt.hu/cgi_bin/njt_doc.cgi?docid=118146.320191\#foot1
} 
rendelkezésre állásával, az infrastruktúra fenntartásával kapcsolatban felmerülö költségek alapján járul hozzá a rendszer finanszírozásához. Európában mindkét megoldást alkalmazzák, például Brémában ${ }^{28}$ kéttényezős a díj, míg Bécsben ${ }^{29}$ egytényezős, vagyis csak az ürméretet és az ürítési gyakoriságot veszik alapul. A Ht. hatályos 46. és 47. §-ai alapján a közszolgáltatási díj akár egy-, és akár kéttényezős is lehet, ${ }^{30}$ de a - vegyes, tehát nem elkülönítetten gyüjtött - hulladék mennyiségével ${ }^{31}$ mindenképp arányosnak kell lennie. A díj mértékének meghatározásakor a tágabb értelemben vett költségeket, ${ }^{32} \mathrm{de}$ a különböző támogatásokat és a hasznosításból elérhető bevételeket is figyelembe kell venni. Ennek tükrében a kérdés az lehet, hogy miként, milyen arányban állnak össze a díjban a költségelemek. $^{33}$

A hulladékkezelési közszolgáltatásban is célszerünek tünik a kéttényezős díj általános alkalmazása, jóllehet nem hálózatos szolgáltatásról van szó. A mért mennyiség figyelembe vétele itt is, ahogyan egyes hálózatos iparágakban is aktuális. ${ }^{34}$ Persze, meg kell oldani a mérés hitelességét, és kezelni kell az esetleges fogyasztói panaszokat. ${ }^{35}$ A környezetvédelmi kérdés azonban az, hogy miként biztosítható a szükséges fejlesztések és az infrastruktúra fenntartásának költsége, illetőleg hogyan lehet a fogyasztókat (itt: ingatlanhasználókat) környezettudatos fogyasztásra (hulladéktermelésre) ösztönözni.

Ezek álláspontom szerint nem választhatók el egymástól, ugyanakkor javarészt megint csak a helyi adottságok szerinti - differenciálást igényelnek. Ha pusztán a pénzügyi szempontokat (megtérülés) nézzük, és egyetlen (nemzeti) közszolgáltatót feltételezünk, akkor az egységes, központi díjszabás akár jó megoldás is lehetne, ${ }^{36}$ viszont attól tartok, a helyi sajátosságok érvényesítése, a fogyasztók és a közszolgáltató(k) illetve önkormányzatok érdekeltsége - a környezeti és a pénzügyi költségek csökkentésében - nehezebben ösztönözhető.

A kéttényezős díj a környezethez való jog (a környezeti fenntarthatóság) szempontjából is indokolt: a szennyező fizet elvének az felel meg, ha az adott - környezeti vagy környezeti eredetü - szolgáltatás valamennyi járulékos költségét ${ }^{37}$ fedezik az egyes díjak. ${ }^{38}$ Ez egyúttal ösztönzi a fogyasztót a tudatos - adott esetben kevesebb - fogyasztásra. Az ösztönző hatás azonban csak akkor érvényesül, ha a fogyasztó pontosan - hiteles és valós idejű adatokból látja a hulladékmennyiség alakulásának hatását a díjra, és ez kéttényezős díj esetén jobban megvalósítható, mint egytényezős díjnál.

\section{Sokat akar a szarka...}

A díjszabályozással kapcsolatban sok a bizonytalanság. A Ht-be 2012-ben átmeneti szabályok kerültek, arra az időre, amíg nem születik meg a törvényi felhatalmazáson alapuló miniszteri rendelet. Ez a rendelet azonban máig nem született meg, s továbbra is hatályos a már említett, 64/2008-as kormányrendelet a települési hulladékkezelési közszolgáltatási díj

\footnotetext{
${ }^{28} \mathrm{http} / /$ transparenz.bremen.de/sixcms/detail.php?gsid=bremen2014_tp.c.64051.de\&asl=bremen203_tpgesetz.c.5 5340.de\&template=20_gp_ifg_meta_detail_d

${ }^{29} \mathrm{https}$ //www.wien.gv.at/umwelt/ma48/tarife/hausmuell.html

${ }^{30}$ Utóbbi esetben ún. rendelkezésre állási és ürítési díjból tevődik össze.

${ }^{31}$ A törvény nem mond sem térfogatot sem tömeget.

${ }^{32} \mathrm{Pl}$. a lerakó későbbi bezárásának, rekultivációjnak költségeit.

${ }^{33}$ Ami nem azon múlik tehát, hogy a mért tömeget vagy a térfogatot veszik-e figyelembe.

${ }^{34}$ A víz, távhő- és a gázszolgáltatás körében sem teljes körüen megoldott még a mérés, sokhelyütt átalányt fizetnek a fogyasztók, ami a hulladékágazat eddigi - mérés nélküli - megoldásához hasonlítható.

${ }^{35}$ A méröeszköz itt aligha kerülhet a fogyasztó birtokába.

${ }^{36}$ Ámbár a díj mértékének a „rezsicsökkentés” szellemében való rögzítése és/vagy a központosítás költségeinek a beépítése előre kódolhatja a szennyező fizet elvének a feláldozását.

${ }^{37}$ Úgy mint kiaknázás, szolgáltatás, infrastruktúra - környezetterhelés, károk helyreállítása, stb.

${ }^{38}$ Illetve díjak, járulékok, bírságok, stb. együttesen - tekintettel az anyag- és energiaáramok többszereplős voltára.
} 
megállapításának részletes szakmai szabályairól. A kormányzati kommunikáció ${ }^{39}$ a lakosság megnyugtatását célozza: a díjak rendszerének változása eszerint a polgárokat nem érinti majd, $\mathrm{s}$ a rezsicsökkentés sem vész el. ${ }^{40} \mathrm{~A}$ díjfizetés módjára vonatkozó változások már körvonalazódnak, a 69/2016. (III. 31.) Korm. rendelet ${ }^{41}$ szerint egy nemzeti koordináló szervezet lép be az ingatlanhasználók $\mathrm{s}$ a közszolgáltatók közé. A tömeg szerinti díjszabás hosszabb távú ${ }^{42}$ elképzelésére vonatkozó részletek azonban még nem láttak napvilágot. Összességében úgy tünik, hogy egy gyökeres változást, „metamorfózist” ${ }^{\text {43 }}$ megélő ágazatban, ahol alig követhetők a kormányzati elképzelések, jogszabályváltozások, nehéz egy-egy kérdésben, így a díjszabással kapcsolatban is állást foglalni. Túl sok a „ha,” a spekuláció, s nem történik meg a lakosság felkészítése. A szolgáltatást igénybevevők magatartásán pedig nagyon sok múlik. Különösen akkor, ha a központosítás miatt helyben eleve kevesebb lehetőség nyílik a szereplök ösztönzésére. ${ }^{44}$

\footnotetext{
$39 \mathrm{http} / /$ www.kormany.hu/hu/nemzeti-fejlesztesi-miniszterium/fejlesztes-es-klimapolitikaert-valamint-kiemeltkozszolgaltatasokert-felelos-allamtitkarsag/hirek/aprilistol-indul-az-uj-orszagosan-egysegeshulladekgazdalkodasi-rendszer

${ }^{40}$ A lényeg egyelöre, hogy a díjak akár még csökkenhetnek is.

${ }^{41} \mathrm{http} / / /$ njt.hu/cgi_bin/njt_doc.cgi?docid=194744.320270

${ }^{42} \mathrm{http}$ ://online-kalkulator.hu/szemetszallitasi-dij-20162017-valtozhatnak-a-szemetdijak/

${ }^{43} \mathrm{http}: / /$ emla.hu/sites/default/files/EMLA 20_kiadvany.pdf

${ }^{44} \mathrm{Az}$ ezeket illető kételyeket jól foglalja össze az Országos Környezetvédelmi Tanács 2015. októberi 29-ei állásfoglalása. http://www.oktt.hu/
} 